University of Pennsylvania Carey Law School

Penn Law: Legal Scholarship Repository

Faculty Scholarship at Penn Law

$10-3-2012$

\title{
Competition in Information Technologies: Standards-Essential Patents, Non-Practicing Entities and FRAND Bidding
}

Herbert J. Hovenkamp

University of Pennsylvania Carey Law School

Follow this and additional works at: https://scholarship.law.upenn.edu/faculty_scholarship

Part of the Communications Law Commons, Databases and Information Systems Commons, Entrepreneurial and Small Business Operations Commons, Industrial Organization Commons, Intellectual Property Law Commons, Internet Law Commons, Law and Economics Commons, Other Economics Commons, and the Technology and Innovation Commons

\section{Repository Citation}

Hovenkamp, Herbert J., "Competition in Information Technologies: Standards-Essential Patents, NonPracticing Entities and FRAND Bidding" (2012). Faculty Scholarship at Penn Law. 1854.

https://scholarship.law.upenn.edu/faculty_scholarship/1854

This Article is brought to you for free and open access by Penn Law: Legal Scholarship Repository. It has been accepted for inclusion in Faculty Scholarship at Penn Law by an authorized administrator of Penn Law: Legal Scholarship Repository. For more information, please contact PennlawIR@law.upenn.edu. 


\section{Competition in Information Technologies: Standards-Essential Patents, Non-Practicing Entities and FRAND Bidding}

\section{Herbert Hovenkamp*}

Information technologies for communications, computers and related devices, the internet, financial transactions, and the software they require have become ubiquitous and virtually essential components of modern life. Not only do these enormous industries affect nearly everyone, but many of their markets are moderately to highly concentrated. In addition they often contain specialized assets and in some cases high entry barriers. These suggest a potential for competitive problems. Nevertheless, thanks to innovation and frequent technological revision most of these markets are able to function quite competitively.

The biggest roadblock to competitive performance in information technology markets is a patent system that has served these industries poorly, mainly because of excessive patent issuance and ambiguous patent scope. In these industries the patent system often leads to high transaction costs, typically in the form of litigation costs or unnecessary licensing costs, rather than increased innovation. One important study has found that the patents in information technology markets are worth less than the anticipated private costs of procuring and defending them. ${ }^{1}$ If private value is negative than social value is certainly negative as well, and by a greater amount. This is in sharp

\footnotetext{
* Professor of Law, University of Iowa. This paper derives from a panel discussion on "Information and Antitrust" moderated by the author at the Fordham Competition Law Institute, New York, Sep. 21, 2012. That panel opened with an Antitrust Division policy statement given by Joseph F. Wayland, Acting Assistant Attorney General. See Antitrust Policy in the Information Age: Protecting Innovation and Competition (Statement of Joseph F. Wayland, Acting Assistant Attorney General, Antitrust Division, U.S. Dept of Justice, 21, 2012), available at http://www.justice.gov/atr/public/speeches/287215.pdf (visited Sep 27, 2012). I am also grateful to other panel participants including Professor Mark Patterson, Fordham Law School; Professor Renato Nazzini, Southampton University and Labruna Mazziotti Segni, Milan; Professor Marc Rysman, Boston University Dept. of Economics; and Professor Kai-Uwe Kuhn, Chief Economist, DG Competition, EU Commission, Brussels, on leave from the University of Michigan. Finally, thank you to Barry Hawk for making this valuable annual program possible.

${ }^{1}$ On the public and private costs of patents in information technologies, see JAMES BESSEN \& Michael J. Meurer, Patent Failure: How Judges, Bureaucrats, AND LaWyers Put Innovators AT Risk 11-19, 98-146 (2008). See also Dan L. Burk \& MARK A. LemLey, The PATENT CRisis AND How the Courts CAN SOlve IT (2009).
} 
contrast to other industries, such as chemicals and pharmaceuticals, where the patent system generally performs much better. ${ }^{2}$

One characteristic of the patent system is a great deal of government regulatory supervision over the patent issuance or "prosecution" process. Much of that process is defined in the first instance in the Patent Act $^{3}$ and administered by the U.S. Patent and Trademark Office, a large federal agency that controls patent examination, approval, and some appeals. As a result there is little room for antitrust intervention into the patent issuance process. The patent system may be deeply flawed. It may do more harm than good in at least some markets, and actually serve to hinder rather than promote innovation. Even if that is true, however, antitrust is not the answer. It is not antitrust's purpose to control shortcomings in federal regulatory processes. ${ }^{4}$

Once a patent is issued, all of this changes. The patent becomes an asset subject to very little more regulatory intervention than is true of most types of personal property. No government agency actively supervises licensing, assignment (transfer), or for the most part, patent use. As a result, application of the antitrust laws need not be detained by regulatory immunity or some other form of deference to an alternative regulatory regime. About the only relevant things that the United States Patent Act says about issued patents is that the patentee is entitled to an action for infringement, ${ }^{5}$ that patents may be transferred and have the characteristics of personal property, ${ }^{6}$ that they may be licensed and that the licenses may contain certain types of vertical restrictions, particularly territorial restrictions. ${ }^{7}$ In addition, $\$ 271(d)$ of the Patent Act provides that certain practices shall not be unlawful patent misuse, including tying in the absence of market power, or refusals to license. When the refusal to license provision was passed, in $1978,{ }^{8}$ the penalty for patent misuse was loss of all patent rights until the misuse was

\footnotetext{
${ }^{2}$ BESSEN AND MEURER, supra.

${ }^{3} 35$ U.S.C.

${ }^{4}$ On this point, see Christina Bohannan \& HeRbert Hovenkamp, CReation Without

RESTRAINT: PROMOTING LIBERTY AND RIVALRY IN INNOVATION 13 (2012).
}

535 U.S.C. $\$ 281$.

${ }^{6} 35$ U.S.C. $\S 261$ (permitting assignment in writing, and declaring that a patent has the attributes of personal property).

${ }^{7} 35$ U.S.C. $§ 261$ ("The applicant, patentee, or his assigns or legal representatives may in like manner grant and convey an exclusive right under his application for patent, or patents, to the whole or any specified part of the United States.").

${ }^{8} 35$ U.S.C. $\S 271(d)(4) \&(5)$. 
purged. ${ }^{9}$ The provision was not intended to change patent law's remedial structure in infringement cases, and in its eBay decision the Supreme Court held that the four traditional principles of equity determine whether a patentee is entitled to an injunction against infringement or must be limited to damages. In order to obtain an injunction,

A plaintiff must demonstrate: (1) that it has suffered an irreparable injury; (2) that remedies available at law, such as monetary damages, are inadequate to compensate for that injury; (3) that, considering the balance of hardships between the plaintiff and defendant, a remedy in equity is warranted; and (4) that the public interest would not be disserved by a permanent injunction. ${ }^{10}$

As a result a firm seeking to use another's patent may not use the patent free of any royalty if the patentee refuses to license, which would be the case under a misuse rule. Rather, the person seeking to use the patent may be entitled to do so upon payment of a royalty, which can be either privately negotiated or else determined judicially in a damages action, and perhaps derived from a prior course of action.

Most of the reluctance to apply the antitrust laws to issued patents is a function of patent ambiguity, a characteristic that is partly inherent in patents and partly a function of a patent issuance processes that has not insisted on sufficient clarity in drafting. If a patentee is really in "possession" of the patented technology when a patent application is approved - a prerequisite to patent issuance ${ }^{11}$-- then it should not be terribly difficult for a trained reader to determine patent boundaries or validity. ${ }^{12}$

The law could greatly improve patent clarity by placing the burden of ambiguity more directly on the patentee, as it generally is in cases involving real property, form contracts, or contracts of insurance. If ambiguities were construed in favor of alleged infringers rather than patentees, the result would almost certainly be a significant change in patent drafting practices, emphasizing clarity of expression rather than breadth of claim. ${ }^{13}$ This might even lead to the result that courts would not approve anticompetitive patent settlements, such as the "pay for delay" settlements that many courts have approved in the pharmaceutical industry under the Hatch-Waxman Act,

\footnotetext{
${ }^{9}$ Morton Salt Co. v. G.S. Suppiger Co., 314 U.S. 488, 493 (1942); U.S. Gypsum Co. v. Nat'1 Gypsum Co., 352 U.S. 457, 465 (1957).

10 eBay Inc. v. MercExchange, L.L.C., 547 U.S. 388, 391 (2006).

${ }^{11}$ E.g., Boston Scientific Corp. v. Johnson \& Johnson, 647 F.3d 1353, 1362 (Fed. Cir. 2011); Ariad Pharm., Inc. v. Eli Lilly \& Co., 598 F.3d 1336 (Fed. Cir. 2010). See BoHannan \& HOVENKAMP, supra note 4 at 65-78.

${ }^{12}$ See BESSEN \& MEURER, supra note 1 at 46-72.

${ }^{13}$ See BOHANNAN \& HovENKAMP, supra note 4 at 78-82, 122-132.
} 
simply because they are loathe get involved in questions about patent validity and scope. $^{14}$

Many of the issues confronting patents in information technologies today do not require courts to break into negotiated patent settlements. Typically at the time of the litigation nothing has been settled, or the transaction is not a settlement at all. In addition, many transactions can be antitrust violations whether or not a patent dispute and settlement were lurking in the background, because the transaction itself is unlawful. For example, patent assignments, which are transfers from one owner to another, are fully reachable under $\$ 7$ of the Clayton Act if they meet its "may substantially lessen competition" standard. ${ }^{15}$ A patent is a productive asset, and under the antitrust standard asset transfers are unlawful if they are likely to result in lower market output or higher market prices. ${ }^{16}$ Other agreements can violate $\S 1$ of the Sherman Act if they restrain trade, and still others can be unlawful exclusionary practices governed by $\S 2$ of the Sherman Act. ${ }^{17}$

${ }^{14}$ The antitrust legality of pay-for-delay settlements is currently subject to a conflict among the Circuit Courts of Appeal. See in re K-Dur Antitrust Litigation, 686 F.3d 197 (3d Cir. 2012) (disapproving settlement); in re Cardizem CD Antitrust Litig., 332 F.3d 896 (6 ${ }^{\text {th }}$ Cir. 2003) (same); Valley Drug Co. v. Geneva Pharms., Inc., 344 F.3d 1194 (11 ${ }^{\text {th }}$ Cir. 2003) (approving settlement); Schering-Plough Corp. v. FTC, 402 F.3d 1056 (11 ${ }^{\text {th }}$ Cir 2005) (same); Tamoxifen Citrate Antitrust Litig., 466 F.3d 187 (2d Cir. 2006) (same); in re Ciprofloxacin Hydrochloride Antitrust Litig., 544 F.3d 1323 (Fed. Cir. 2008) (same). On pay for delay settlements, see 1 Herbert Hovenkamp, Mark D. Janis, Mark A. Lemley, and Christopher R. Leslie, IP and Antitrust: An Analysis of Antitrust Principles Applied to Intellectual Property Law Chs. 7 \& 15.3 (2d ed. 2010 \& 2012 Supp.); 12 HerberT HovenKAMP, ANTITRUST LAW II2046c (3d ed. 2012); C. Scott Hemphill \& Mark A. Lemley, Earning Exclusivity: Generic Drug Incentives and the Hatch-Waxman Act, 77 Antitrust L.J. 947 (2011); C. Scott Hemphill, An Aggregate Approach to Antitrust: Using New Data and Rulemaking to Preserve Drug Competition, 109 Colum. L. Rev. 629 (2009); Michael A. CARRIER, InNOVATION FOR THE 21 ST CENTURY: HARNESSING THE POWER OF INTELLECTUAL PROPERTY AND ANTITRUST LAW 345-71 (2009).

${ }^{15}$ See 15 U.S.C. $\S 18$. On patents as assets, see 5 PhILlip E. ArEEDA \& Herbert HovenKamp, ANTITRUST LAW II1202f (3d ed. 2009).

${ }^{16}$ See Louis Kaplow, Market Definition and the Merger Guidelines, 39 Rev. Indus. Org. 107, 122-23 (2011); and see Herbert Hovenkamp, Markets in Merger Analysis, 57 Antitrust Bull. \#3 (2012) (in press) currently available at http://papers.ssrn.com/sol3/papers.cfm?abstract_id=1945964.

${ }^{17}$ See 12 Herbert HovenKAMP, ANTITRUST LAW II2046 (3d ed. 2012). 


\section{Standards Essential Patents}

One almost omnipresent component in information technologies is standard setting, driven by the need for compatibility across networks that contain numerous participants. Notwithstanding some competitive risks, ${ }^{18}$ collaborative standard setting is presumptively a good thing, particularly when one considers the alternative. The monolithic controller of a network, such as AT\&T prior to its 1982 breakup, ${ }^{19}$ may have little need for standards to the extent that it makes every product and controls every transaction that occurs on the network. In more dominated networks, such as Microsoft's Windows system, standards are essential but many may be imposed from the top down, as when Microsoft instructs independent software developers in the protocols necessary to achieve compatibility. As networks become more competitive, however, more collaborative standard setting is necessary. ${ }^{20}$ Today virtually every interactive technology incorporated into a cellular phone, computer, digital camera or similar devices is governed by a standard. Additionally, some standards are used to reduce information costs or achieve uniformity in non-interactive devices. A famous example in antitrust law is the Allied Tube case, which involved a national standard for electric conduit which was promulgated by an organization concerned with establishing uniform standards for building products. ${ }^{21}$ Although electric conduit and most other building products are not networked in any strong sense, standard setting is nevertheless important for two reasons. First, designing a state or municipal building code is costly, and would be prohibitively costly if every city across the country had to test products individually for safety or functionality. Second, manufacturing and distribution of building products, many of which are sold in nationwide markets, would be much more costly if manufacturers had to comply with diverse and often mutually exclusive standards in different areas.

However, the Allied Tube decision illustrates what can happen when standards are used anticompetitively. The plaintiff had developed plastic (PVC) conduit, a revolutionary product that eventually stole most of the market from steel conduit, because PVC was less costly, easier to work with, and nonconductive. The defendant Allied Tube and others developed a scheme to "pack" the standard setting organization (SSO) and obtain disapproval of plastic conduit, with the result that it was for a time prohibited by local building codes. The case illustrates that anticompetitive standards can restrain not merely price and output, but also in some cases can prevent a superior

\footnotetext{
${ }^{18}$ See 12 Id. at II2014 (threat of collusion); 13 id. at III2230-2235 (3d ed. 2012) (possibility of anticompetitive exclusion).

${ }^{19}$ United States v. AT\&T, 552 F. Supp. 131, 136 (D.D.C. 1982), aff 'd mem. sub nom., Maryland v. United States, 460 U.S. 1001 (1983).

${ }^{20}$ See 13 Herbert HovenKAMP, ANTITRUST LAW IIII2230-2235 (3d ed. 2012).

${ }^{21}$ Allied Tube \& Conduit Corp. v. Indian Head, Inc., 486 U.S. 492, 494 (1988).
} 
product from coming to market. The standard operates as a socially costly restraint on innovation. ${ }^{22}$

Participation in SSOs is usually voluntary, but access to existing standards is often essential if a producer wishes to supply its product or service "on the network." For example, cellphones must be able to connect into the wireless system and in some cases the internet. Memory devices for computers or video cameras must be compatible if the hardware itself is to be transportable, or if the files or images they read or create are to be shared. In some cases the standard that an SSO adopts is already in the public domain, perhaps because the relevant patents have expired, have been dedicated to the public by their users, or are part of an open source arrangement. In other cases the SSO may believe that the standard it is adopting is in the public domain, but may find out only later that the standard actually infringes someone's patent. This may happen inadvertently, or it may happen if a patentee intentionally withheld information about its technology. ${ }^{23}$

Intentional withholding can also take different forms. First it may occur because a patentee takes advantage of the "gap" between patents, which become public upon issuance, and patent applications, which have priority over later developed technology but are not published for the first eighteen months after the filing date. ${ }^{24}$ This problem in turn can be magnified by the patent continuation process, by which patent claims can be added or broadened as long as a patent is pending and even after issuance in some cases. ${ }^{25}$ A firm actively participating in an SSO might be surreptitiously modifying its patent claims so as to cover a standard that the SSO is in the process of developing. It may then lie in wait until other members have made a significant investment in the standardized technology, announcing its patents at a time when it can extract the largest possible royalty. Finally, intentional withholding may occur because patents are ambiguous and costly to interpret; so a patent owner might simply wait until after the standard has been deployed to announce its belief that its patent has been infringed.

${ }^{22}$ See BoHANNAN \& HovenKAMP, supra note 4 at 238-257.

${ }^{23}$ E.g., Rambus Inc. v. FTC, 522 F.3d 456 (D.C. Cir. 2008), cert. denied, 555 U.S. 1171 (2009); see also In re Dell Computer Corp., 121 F.T.C. 616 (1996) (computer manufacturer participated in standard-setting organization and certified that it did not have IP rights on developing standards when in fact it did).

2435 U.S.C. $\S 122(\mathrm{~b})(1)$.

${ }^{25}$ Mark A. Lemley \& Kimberly A. Moore, Ending Abuse of Patent Continuations, 84 B.U. L. Rev. 63, 70 (2004); Michael J. Meurer \& Craig Allen Nard, Invention, Refinement and Patent Claim Scope: A New Perspective on the Doctrine of Equivalents, 93 Geo. L.J. 1947, 1993 (2005). 
As a result it is critically important from the onset that an SSO insist that its members make a commitment about their own patents as a condition of their participation. The standard setting process is typically not run by lawyers but rather by electrical engineers, product managers, or other people whose technical training is in some area other than law. As a result, the process has sometimes reflected considerable naiveté about the strategic possibilities that can arise. This was true, for example, in the Rambus case, where JEDEC, the standard setting organization, did not do an adequate job of making such precommitments clear. ${ }^{26}$

At the time such precommitments are called for the participants are typically acting under a great deal of uncertainty about the value of their respective technologies. ${ }^{27}$ Alternatively, if they have no technologies to offer themselves, they will not be clear about how much they will be expected to pay. For example, an SSO may begin considering technologies for a particular feature that limits undesirable noise in audio transmissions. The choices may be patented technologies Alpha, Beta, and Gamma, and also technology Delta, whose patent has expired. Delta may not be quite as good as the patented alternatives, but it is free. Until the owners of patented technologies Alpha, Beta and Gamma have made commitments they are all likely to have positive but uncertain costs. To the extent that any questions persist about the validity or scope of Alpha's, Beta's, or Gamma's patents there may be additional uncertainty.

This is where the FRAND royalty comes in. FRAND refers to a firm's commitment to make its technology available at a "fair, reasonable and nondiscriminatory royalty" if it is adopted as the standard. ${ }^{28}$ That is, the FRAND commitment is a form of bidding. Typically the FRAND commitment is not a promise to charge any particular price, but only a price that meets the FRAND expectations. For example, the Ninth Circuit quoted this typical FRAND provision:

The Patent Holder will grant a license to an unrestricted number of applicants on a worldwide, non-discriminatory basis and on reasonable terms and conditions to

\footnotetext{
${ }^{26}$ Rambus, 522 F.3d at 467-69.
}

${ }^{27}$ See Doug Lichtman, Understanding the RAND Commitment, 47 Hous. L. Rev. 1023, 1039-43 (2010); Joseph Scott Miller, Standard Setting, Patents and Access Lock-In: RAND Licensing and the Theory of the Firm, 40 Ind. L. Rev. 351, 358 (2007); Daniel G. Swanson \& William J. Baumol, Reasonable and Nondiscriminatory (RAND) Royalties, Standards Selection, and Control of Market Power, 73 Antitrust L.J. 1, 7-11 (2005); Mark A. Lemley, Intellectual Property Rights and Standard-Setting Organizations, 90 Cal. L. Rev. 1889 (2002).

${ }^{28}$ The United States literature often speaks of "RAND" royalties, thus explicitly requiring that the royalty be "reasonable" but not necessarily that it be "fair." Today the two terms are generally used interchangeably, as they are in this paper. 
use the patented material necessary in order to manufacture, use, and/or sell implementations of the above ... Standard. ${ }^{29}$

This commitment permits the members of the SSO to focus on technical issues and worry about the price later. Of course, if the commitment meant nothing at all, then the concept of FRAND would largely lose its value. Nevertheless, computing FRAND royalties in the first instance after the FRAND commitment has been made is not easy. ${ }^{30}$ It may become much easier, however, after the FRAND-encumbered patent has been licensed to others, thus creating a "yardstick" for measuring future royalties. The nondiscrimination provision creates at least a strong presumption that the terms given to a first licensee will also apply to subsequent licensees. ${ }^{31}$

FRAND obligations tend to "level" the value of patents in the sense that they apply a uniform royalty measure to patents that are declared essential. Of course, patentees can be expected to claim that their particular patent is unusually valuable because of the features that it covers. Patents have market value, however, not intrinsic value. Their value depends on the cost of the next-best alternative. A patent may cover sixteen different "essential" things in a device, but if one or a set of alternative patents or public domain technologies can do these things as well the value of the patent must be measured against these alternatives. For example, clean drinking water is "essential," but if six different technologies are available to filter water effectively, then the value of any particular patent is the price it would claim in a market in which the six technologies bid against each other.

Of course, once a patent is declared by an SSO to be standards essential and incorporated into technology, the bidding is over. If we ignore the FRAND commitment, the patent's value is largely determined by the costs of extraction from that particular technological element, not from anything inherent in the patent itself. Further, firms know all of this in advance, so if they wish to assert later that a particular patent within their standards-adaptable portfolio is unusually valuable, they can always say so and leave the SSO to decide whether or not to adopt it. ${ }^{32}$ Absent that, there does not seem

${ }^{29}$ Microsoft Corp. v. Motorola, Inc., _ _ F.3d _, 2012 WL 4477217 ( $9^{\text {th }}$ Cir. 2012)

${ }^{30}$ See in particular Judge Posner's opinion in Apple, Inc. v. Motorola, Inc., __ F. Supp. 2d _ , 2012 WL 2376664 (N.D. Ill. June 22, 2012).

${ }^{31}$ See Joseph F. Wayland, Dep't of Justice, Antitrust Policy in the Information Age: Protecting Innovation and Competition (Sept. 21, 2012), at *5-6, available at http://www.justice.gov/atr/public/speeches/287215.pdf.

${ }^{32}$ See Microsoft Corp. v. Motorola, Inc., F.3d 2012 WL 4477217 ( $9^{\text {th }}$ Cir. 2012) ("Motorola made promises to the ITU to license its standard-essential patents worldwide to all comers. In exchange, it received the benefit of having its patents implicated in the standards. 
to be any good reason for not treating all patents alike, and the cost of determining individual value would very likely swamp the entire system.

\section{Estimating FRAND Royalties}

"FRAND" typically refers to a rather nonspecific agreement among participants to bargain about technology first, while deferring questions about specific royalties to later. The Patent Act itself specifies that a patentee in an infringement action is entitled to damages that are not less than a "reasonable royalty," 33 but identification of a reasonable royalty in infringement cases has become an extremely costly and often indeterminate process. Further, as noted below, royalties developed as damages in a patent infringement action may differ in important respects from royalties negotiated at arms' length in a market. To the extent that a FRAND commitment is contractual damages should reflect the arms length bargaining setting rather than the litigation setting.

In the FRAND context, the term "nondiscriminatory" means an absence of third degree price discrimination, which occurs when a seller charges two or more different prices to two or more distinctively identified groups of customers. The term certainly does not refer to a promise not to engage in second degree price discrimination, which refers to such things as quantity based pricing. For example, a patentee that charges a royalty of five cents per unit discriminates between the licensee who sells 100 units and the one who sells 1000, because its costs of licensing are the same for both. But such discrimination is inherent in the per unit, per dollar, or other "per click" licensing terms that are common in patent licensing, including FRAND licensing.

The important questions that a FRAND commitment typically leaves open is the base upon which the royalty rate must be computed and the royalty rate. As to the base, a memory chip in a GPS device may be covered by 10 patents, one of which is subject to a FRAND commitment. Should the royalty percentage (whatever it may be) be computed on the chip, the GPS device that contains the chip, or the automobile that contains the GPS device ${ }^{34}$ In general, the royalty must reflect a base that identifies the

Motorola could have withheld the promise at the price of having the ITU avoid its patents when setting standards, but chose not to.").

${ }^{33} 35$ U.S.C. $§ 284$ (“...damages adequate to compensate for the infringement, but in no event less than a reasonable royalty for the use made of the invention....").

${ }^{34}$ See Eingestellt von Florian Mueller um, Newly-Discovered Apple Letter to Wireless Standards Body Proposed Solution to Rampant FRAND Abuse, Foss PATENTS (Feb. 8, 2012, 11:41 AM), http://www.fosspatents.com/2012/02/newly-discovered-apple-letter-to.html (visited Sep 26, 2012). See also Ove Granstrand \& Marcus Holgersson, The 25\% Rule Revisited and a New Investment-Based Method for Determining FRAND Licensing Royalties, 47 les Nouvelles, No. 3 (2012). 
functionality to which that particular patent is tied. ${ }^{35}$ Second, it must include a realistic apportionment of the overall number of patents included in a device. For example, someone who claims that an accused device infringes 10 of its patents and seeks a $3 \%$ royalty, but who later establishes infringement of only one patent, should not be heard to say that this one patent deserves the entire $3 \%$ royalty. ${ }^{36}$ Presumptively, it deserves one tenth of that amount.

The federal courts have increasingly rejected an "entire value" method that identifies the "gross" product as the base for measuring royalties. Instead, they are moving toward a "smallest salable patent practicing unit" measure in ordinary patent infringement actions where damages are based on per unit royalties. As the Federal Circuit recently observed,

damages must be awarded "for the use made of the invention by the infringer." ${ }^{37}$ Where small elements of multi-component products are accused of infringement, calculating a royalty on the entire product carries a considerable risk that the patentee will be improperly compensated for non-infringing components of that product. Thus, it is generally required that royalties be based not on the entire product, but instead on the "smallest salable patent-practicing unit." 38

The court took the same approach in Lucent Technologies, when it rejected an expert report concerning a relatively minor patent for entering information into fields on a computer with a touchscreen without using the physical keyboard, but which based royalties on the value of the entire computer in which the accused method was employed. $^{39}$ The court held that a patentee could base damages on the value of the entire product only by showing that "the patent-related feature is the "basis for customer demand" of the entire good. ${ }^{40}$ It relied on nineteenth century decisions holding that

${ }^{35}$ See, e.g., Uniloc USA, Inc. v. Microsoft Corp., 632 F.3d 1292 (Fed. Cir. 2011); IP Innovation L.L.C. v. Red Hat, Inc., 705 F. Supp. $2 d 687$ (E.D. Tex. 2010).

${ }^{36}$ Apple, Inc. v. Motorola, Inc., __ F. Supp. 2d _ , 2012 WL 2376664 at *11 (N.D. Ill. June 22, 2012).

${ }^{37}$ Citing 35 U.S.C. $\$ 284$.

${ }^{38}$ LaserDynamics, Inc. v. Quanta Computer, Inc., __ F.3d _ 2012 WL 3758093 (Fed. Cir. Aug. 30, 2012), quoting Cornell Univ. v. Hewlett-Packard Co., 609 F.Supp.2d 279, 287-288 (N.D.N.Y. 2009).

${ }^{39}$ Lucent Technologies, Inc. v. Gateway, Inc., 580 F.3d 1301 (Fed.Cir. 2009). The method consisted in using a keyboard displayed on the screen together with a calculator, and touching the screen directly. The patentee did not claim to invent the touchscreen itself.

${ }^{40}$ Id. at 1336. 
when a patent is on an improvement rather than the original machine, damages based on reasonable royalties must be confined to the value of the improvement. ${ }^{41}$

The "basis for customer demand" language is not particularly helpful. A computer may have patents on memory chips, processor chips, storage devices, controllers, all of which are essential to the functioning of the computer. In addition, each of these things forms a "basis for consumer demand" to the extent that consumers do not want to purchase a computer that lacks any one of them. The value of any "essential" component effectively becomes the value of the entire device to the extent that the device is worthless without it. But ten essential components cannot each claim to represent the value of the entire device.

In any event, the size of the base is largely irrelevant if one can freely inflate the royalty rate. The Lucent decision addressed an attempt to do that. Forbidden from estimating a reasonable royalty at $1 \%$ of the entire computer, the expert revised his opinion to base royalties only on Microsoft Outlook, a portion of Microsoft's Office software thought to be the smallest saleable unit upon which royalties could be based, but then he raised the royalty rate to $8 \%{ }^{42}$

While the use of the smallest saleable unit as a base for estimating royalties is not free from problems, it does have the value that it provides a more-or-less common and objectively measurable currency for assessing the size of the royalty base. At that point the market itself will hopefully provide yardsticks for computing the size of the royalty, using negotiated royalties rather than damage awards as the yardstick. That is, damages measurement in an infringement case involving a FRAND-encumbered patent should be different from damages in patent cases generally.

The reason to use negotiated royalties rather than damages awards based upon a reasonable royalty standard lies in one important difference in how royalties are computed in arms length as opposed to litigation settings. In the standard-setting process proffered technology is probabilistic in the dual sense that (1) the patents being offered have typically not been litigated in order to establish validity or scope; and (2) the SSO typically has alternative technologies to choose from in selecting a standard. By contrast, in the litigation context the infringement defendant has already "selected" the standard by virtue of its infringement, and the patent has already been determined or acknowledged to be valid. When we are dealing with ex ante FRAND commitments rather than ex post infringement, it is the ex ante value that should be accorded the

${ }^{41}$ Garretson v. Clark, 111 U.S. 120 (1884); Seymour v. McCormick, 57 U.S. (16 How.) 480, 491 (1853).

${ }^{42}$ Lucent, 580 F.3d at 1301, 1338 ("Being precluded from using the computer as the royalty base, he used the price of the software, but inflated the royalty rate accordingly.").. 
weight. ${ }^{43}$ For example, in a breach of contract action in which the plaintiff contractor had bid on the job in a competitive market, it would not be proper to look at the price charged in a monopoly transaction to determine damages.

In spite of their many ambiguities, open ended FRAND commitments are a valuable and competitive tool, given the uncertainty that exists at the time the commitments must be made. Standard setting would be a much more costly and indeterminate process without them. FRAND royalties should generally be low and manageable by default, because SSO participants can always "bid" for a higher royalty ex ante, and then the SSO can decide which technology to accept on the basis of the proffered price.

The non-practicing entity (NPE) that declines to participate in the SSO process should generally be held to the same price as the measure of its damages. That is so say, a "reasonable" royalty is the royalty that the NPE would have obtained in the competitive market in which it might have participated but declined to do so. The case for measuring NPE damages in this way is strongest when the NPE had actual knowledge of the SSO process but declined to participate, or when an objectively reasonable NPE would have known about the process. The case is weakest when the SSO's processes were not well communicated to outsiders or the NPE in question was not permitted to participate.

The FRAND process permits SSOs to select a standard based upon performance characteristics on the assumption that all of the standards will be reasonably priced, without worrying too much about exactly what that price will be. Once the standard is adopted, however, the patents that write on that standard become "essential" to the extent that the standard is a necessary component of the network. The change in the financial positions of those offering the alternative technologies can be dramatic. To return to the previous hypothetical, prior to standard adoption patents Alpha, Beta, and Gamma competed to be selected as the standard. If Alpha's technology is adopted the result will be an immediate and very substantial increase in Alpha's value because it is now a "standards essential patent" (SEP). By contrast, Beta and Gamma were not adopted. In an extreme case those patents might become worthless. This would be true, for example, if the technologies that those patents cover has no market other than inclusion as the standard for this particular SSO. ${ }^{44}$ Further, as

${ }^{43} \mathrm{Cf}$. Judge Posner's conclusion the the FRAND royalty analysis should start out "with what the cost to the licensee would have been of obtaining, just before the patented invention was declared essential to compliance with the industry standard, a license for the function performed by the patent.” Apple, Inc. v. Motorola, Inc., _ _ F.Supp.2d _ , 2012 WL 2376664 at *11-12 (N.D.Ill. June 22, 2012).

${ }^{44}$ See, e.g. Golden Bridge Tech., Inc. v. Motorola, Inc., 547 F.3d 266 (5th Cir. 2008) (rejecting antitrust boycott claim by plaintiff whose technology was not accepted as a standard for wireless communication technologies). 
time goes on the manufacturers participating in this standard will invest in production facilities and begin producing under the standard, typically making a switch very costly.

Alpha's position, of course, is that its patent has become immensely valuable, but might be even more valuable if it could be freed from its FRAND commitment. Alpha is a little like the contractor who submits a winning low bid but later realizes that the seller might have been willing to pay more. Alpha can thus be expected to do what it lawfully can in order to increase the value of its patent which has now become standards essential. First, it might use the negotiation process to try to maximize royalties by getting a high royalty rate or a larger base for computing royalties. Second, it might seek to evade the consequences of its FRAND obligation altogether.

\section{Transfers and Injunctions Involving FRAND Encumbered Patents}

Interpreting FRAND commitments requires courts to fill in the gaps in incomplete contracts. ${ }^{45}$ Assessing the base and royalty rate poses one set of problems. Another set relates to "evasion" devices -namely, transfers and injunctions

Should FRAND commitments "run with the land," in the sense that owners of FRAND-encumbered patents should not be able to free them from FRAND commitments simply by assigning the patents to someone else? One fundamental principle of property law is that a property owner cannot transfer away a larger interest than it owns. Of course, that may beg the question if the issue is what does it own. More fundamentally, the entire FRAND commitment process would be worthless if patentees were able to evade it by the simple device of assigning encumbered patents to someone else in order to remove the encumbrance. As a result the proper default rule is that a FRAND commitment "runs with the patent" so to speak. If a firm wants to transfer less, it should be required to state its wishes up front when technologies are being selected. For example, if a firm wants to limit its FRAND commitment to, say, two years it should be free to do so by declaring as much as part of its original commitment. Then the SSO can consider the offer and compare it with alternatives or make a counter-proposal. By contrast, if a patentee stated up front that it intended to make its FRAND commitment last only until it chose to sell the patent to someone else, whenever that might be, it would be tantamount to no FRAND commitment at all. Some

${ }^{45}$ See e.g., Microsoft Corp. v. Motorola, Inc., _ _ F.3d _ , 2012 WL $4477215\left(9^{\text {th }}\right.$ Cir. Sep. 28, 2012). 
companies, such as Microsoft, have policies to this effect, ${ }^{46}$ but the legal obligation should be clear in any event. ${ }^{47}$

The question of injunctive relief is only a little more complex. A FRAND commitment is on its face an offer to license to all who employ that patent in their standards-compatible product. True, the precise royalty terms are typically not specified in advance, but that entails that the FRAND royalty will be determined by the body, and by reference to common indicia of royalty rates, such as rates paid for similar technologies in the same or perhaps another situation. Further, as noted earlier, the FRAND commitment effectively turns the royalty issues into a breach of contract claim rather than a litigated royalty claim. Permitting the owner of a FRAND-encumbered patent to have an injunction against someone willing to pay FRAND royalties is tantamount to making the patent holder the dictator of the royalties, which once again is the same thing as no FRAND commitment at all. ${ }^{48}$ Permitting an injunction effectively places the patent holder and the potential infringer in the same position that they would be when an innocent infringer invests in a technology and is later taken by surprise by a patent holder, who can then claim royalties whose amount is driven mainly by the infringer's costs of extracting itself from the patented technology.

The Supreme Court's eBay decision overruled a line of Federal Circuit decisions that had made injunctions almost a matter of right in patent infringement cases. ${ }^{49}$ The fact that the patent in question has already been FRAND encumbered establishes that the patentee's reasonable expection was the right to obtain FRAND royalties, not to exclude. Further, inherent in the FRAND requirement is that the royalties be nondiscriminatory - that is, once they are determined any participant has the right to the technology upon payment of that sum. Beyond that, the fact that the patent in question is standards-essential places a heavy thumb on the scales with respect to eBay's public interest requirement. Here, an injunction can potentially hold up an entire network or make it less competitive. In sum, FRAND-encumbered patents should never be enforced by injunction, at least not when the infringement defendant has agreed to pay a FRAND royalty. In its Microsoft decision the Ninth Circuit held as much. ${ }^{50}$

${ }^{46}$ See Microsoft's Support for Industry Standards (Feb. 8, 2012), available at http://www.microsoft.com/about/legal/en/us/IntellectualProperty/iplicensing/ip2.aspx (visited Sep. 26, 2012) (commitment to continue acknowledging FRAND commitments).

${ }^{47}$ See generally Mark A. Lemley, Intellectual Property Rights and Standard-Setting Organizations,_90 CALIF. L.REV. 1889 (2002)

${ }^{48}$ Accord Apple, Inc. v. Motorola, Inc., __ F. Supp. 2d _ , 2012 WL 2376664 (N.D. Ill. June 22, 2012).

${ }^{49}$ eBay Inc. v. MercExchange, L.L.C., 547 U.S. 388, 391 (2006).

${ }^{50}$ Microsoft Corp. v. Motorola, Inc., __ F.3d _ , 2012 WL 4477215 ( $9^{\text {th }}$ Cir. Sep. 28, 2012). 


\section{Exclusion Orders and the International Trade Commission}

On the question of entitlement to injunction, the U.S. International Trade Commission is somewhat unique. The ITC is a regulatory body with quasi-judicial power to exclude certain classes of unlawful imports. Historically the ITC, created in 1916, was concerned with things like dumping and foreign subsidies deemed to make import of the subsidized goods unlawful. More recently, however, the ITC has had a major role to play in the enforcement of United States intellectual property rights abroad by preventing the import into the United States of goods that infringe United States patents, copyrights, or trademarks. ${ }^{51}$ The ordinary remedy granted by the ITC is an "exclusion order," which is not a general injunction prohibiting production but rather a bar from importing the foreign-produced good into the United States. ${ }^{52}$ To the extent that domestic companies outsource production to foreign firms or produce in plants located abroad, they may also be subject to exclusion orders. If a large American firm outsources the production of its products for shipment back into the United States, those goods are within the jurisdiction of the ITC. For example, in May, 2012, the ITC issued an exclusion order against Motorola Mobility upon Microsoft's complaint that certain imported Motorola Mobility devices infringed Microsoft's patents. ${ }^{53}$ In an extreme case where most of a firm's product is made abroad an exclusive order is tantamount to an injunction.

The difficulty with ITC exclusion orders derives from two things. First, because an exclusion order is not literally an injunction but only a prohibition of import, the Federal Circuit has held that it is not covered by the Supreme Court's eBay decision. ${ }^{54}$ Second, the ITC has no independent authority to award damages for patent infringement. The fact that damages are unavailable would ordinarily count in favor of injunctive relief. Equally significant, however, is the fact that once an infringing good is sold in the United States the seller is guilty of infringement and facilitators may be guilty

${ }^{51}$ See Colleen V. Chien \& Mark A. Lemley, Patent Holdup, the ITC, and the Public Interest, Cornell L.Rev. (2012); Sapna Kumar, The Other Patent Agency: Congressional Regulation of the ITC, 61 Fla. L. Rev. 529 (2009).

${ }^{52} 19$ U.S.C. $§ 1337(d)(f)$. A prominent example involving virtually the entire smartphone industry is Certain Electronic Devices with Communication Capabilities, Components Thereof, and Related Software; Notice of Institution of Investigation; Institution of Investigation Pursuant to 19 U.S.C. 1337, 76 Fed. Reg. 60870-01 (Sept. 30, 2011).

${ }^{53}$ See, e.g., In re Certain Mobile Devices, Associated Software, and Components Thereof, Inv. No. 337-TA-744, 2012 WL 3715791 (USITC, May 18, 2012).

${ }^{54}$ See Spansion, Inc. v. ITC, 629 F.3d 1331, 1359 (Fed. Cir. 2010), cert. denied, 132 S. Ct. 758 (2011). The FTC has argued the contrary position. See Federal Trade Comm'n, The Evolving IP MARKETPlace: Aligning PATENT Notice AND REMEDIES WITH COMPETITION 31-72 (2011). 
of contributory infringement or inducement. As a result, the reason that the challenger has gone to the ITC rather than a district court in the first place may be in order to earn a kind of quasi-injunctive relief that it would not obtain from a federal district court. Given that a significant percentage of devices or their components employing standards essential patents are produced abroad for United States markets, a ITC exclusion order can be an effective end run around a FRAND commitment if the ITC issues an exclusion order because of infringement of a FRAND-encumbered patent.

Once again, the reasonable approach for the ITC in such a case is to deny an exclusion order. Significantly, this does not deny the patent holder a remedy. Rather, it relegates the patentee to a federal district court, which can then decide the injunction or damages question in light of the FRAND commitment, eBay, and any other relevant factors. Exclusion orders should be limited to situations representing a manifest unwillingness to pay a FRAND obligation. The Federal Trade Commission has taken that position in an ITC filing. As the Commission observed

The possibility of patent hold-up derives from changes in the relative costs of once competing technologies as a result of the standard setting process. Prior to adoption of a standard, alternative technologies compete to be included in the standard. SSO members often agree to license SEPs on RAND terms as a quid pro quo for the inclusion of their patents in a standard. Once a standard is adopted, implementers begin to make investments tied to the implementation of the standard. Because it may not be feasible to deviate from the standard unless all or most other participants in the industry agree to do so in compatible ways, and because all of these participants may face substantial switching costs in abandoning initial designs and substituting a different technology, an entire industry may become locked in to a standard, giving a SEP owner the ability to demand and obtain royalty payments based not on the true market value of its patents, but on the costs and delays of switching away from the standardized technology. ${ }^{55}$

Nevertheless, the ITC has indicated that it will not refrain from granting an exclusion order simply because the patents upon which the request is based are FRAND encumbered. ${ }^{56}$

55 See in re Certain Gaming and Entertainment Consoles, Related Software, and Components Thereof, Third Party United States Federal Trade Commission's Statement on the Public Interest, Inv. No. 337-TA-752 (USITC, June 6, 2012), available at http://www.ftc.gov/os/2012/06/1206ftcgamingconsole.pdf.

${ }^{56}$ See In re Certain Gaming and Entertainment Consoles, Related to Software, and Components Thereof, Initial Determination, Inv. No. 337-TA-752, 2012 WL 1704137 at *163 (USITC, Apr. 23, 2012). 


\section{Special Problems of Non-Practicing Entities}

A non-practicing entity, or NPE, is a firm that does not make patent-protected goods itself but makes its money by licensing to others or bringing infringement actions. The classical image of the NPE is the firm that developed its own patents internally in its own laboratory or other facility, but then licensed them rather than producing other them. A more recent phenomenon is the firm that acquires patents from others, often in large numbers, and then re-licenses them or brings infringement actions. One of the most important consequences of eBay was for NPEs. Because a nonproducing firm can profit from patents only by licensing them it is very difficult for the NPE to show that damages are an inadequate remedy, as eBay requires. As a result, since eBay most NPEs have been limited to damages. ${ }^{57}$

NPEs have the potential to destabilize the entire standard setting process because they have a different set of incentives from participating members. Whether they agree to FRAND terms depends on the circumstances. First, at the standards adoption, or "bidding" stage the NPE certainly has an incentive to induce the SSO to adopt its own technology as the standard. Returning to the previous example, if the SSO is selecting among patented standards Alpha, Beta, and Gamma, it will presumably apply the same criteria even though Alpha might not be a producer of any good covered by the standard, but merely a patent holder. In order to attain SEP status, Alpha must make the same FRAND commitment as anyone else. On the other side, however, the NPE does not have to worry about infringing the standard once it is adopted, because it does not make anything. As a result it may decide to avoid the standard setting process altogether, hoping to be in a position to bring an infringement action after the standard is deployed. Its incentive to do this may be stronger if it believes it can conceal its own technology from the SSO - for example, if it has a pending but undisclosed patent application covering one or more of the standards, or if its patents are so numerous and ambiguous that the SSO might overlook one or more of them. In general, the more relevant patents the NPE owns and the more costly it is to interpret them, the greater will be its incentive to avoid making any FRAND commitment and stake its royalty claims later.

The lack of FRAND commitments is only part of the story for the NPE, however. Because the NPE is not a potential infringer itself, it faces an entirely different risk profile from producing entities. When the NPE is enforcing FRAND encumbered patents there is no less reason for enforcing the FRAND commitment than when the enforcer is a practicing entity.

The bigger problem involving NPEs is those who have never agreed to FRAND commitments and who threaten infringement actions or request licensing only after the technologies claimed to infringe have been put into place. Even though its NPE status is

\footnotetext{
${ }^{57}$ See Chien \& Lemley, Patent Holdup, supra note 51; BoHANNAN \& HovENKAMP, supra note 4 at 79 .
} 
likely to deny it an injunction, it will be in a position to obtain larger damages because it has not made the FRAND commitment. This problem is hardly confined to the context of standard setting. However, it has become particularly serious in networked communications technologies because of the very large numbers of poorly defined patents.

Here, defects in the patent system (whether inherent or not) account for a great deal of the extra leverage that NPEs enjoy. Perhaps the most significant problem is that patent law provides no protection for the independent developer, as copyright law does. You can infringe a patent even if you have developed the relevant technology entirely on your own. Compound this fact with the extraordinarily high cost of interpreting a patent and the large number of patents at issue, and one soon suspects that the principal thing that patents are contributing to these technologies are transactions costs. The NPE or patent aggregator who owns several thousand patents can go to a producer and claim infringement of various unspecified patents in its portfolio and then ask for a license fee that is much smaller than the cost of ascertaining whether any of the patents cover the producer's technology, leaving aside questions of patent validity. ${ }^{58}$

This is much less likely to occur when both of the parties in question have substantial patent portfolios and each is a producer. In that case each one of them is in a position to make the same offer to the other and we often see a phenomenon called "tacit pooling," in which the equilibrium position is for each firm not to bring suit against the other. ${ }^{59}$ This explains why many producers or their representatives have attempted to acquire large portfolios for defensive purposes. This phenomenon differs from traditional tacit collusion in that it operates pairwise rather than across the entire industry; that is, each firm will decide whether or not to sue the other depending on the size and scope of the other's portfolio. In some cases the best strategy will be to file an infringement suit, particularly if the patent portfolios are seriously uneven in strength, but in others the most profitable strategy will be not to sue. ${ }^{60}$

Tacit pooling is a socially desirable phenomenon in that it permits the firms in question to rely on production of goods rather than litigation for their revenue. Patent aggregators are fashionable today because they are in a stronger position to monetize patents than individual owners. But one must then question the source. Conceivably an aggregation of patents can provide turnkey licensing that eliminates double

${ }^{58}$ See, e.g., Eon-Net LP v. Flagstar Bancorp., 653 F.3d 1314 (Fed. Cir. 2011), cert. denied, 132 S. Ct. 2391 (2012) (finding litigation misconduct in filing of baseless patent claims where cost of obtaining legal opinions on patent validity and infringement greatly exceeded the demand license fee).

${ }^{59}$ See Erik Hovenkamp, Tacit Pooling (2012) (unpublished manuscript on file with author).

${ }^{60}$ Ibid. 
marginalization problems and provides a manufacturer with all of its technology needs for a certain product. Often, however, the source of additional revenue is nothing more than the increased transaction costs that can be threatened against producers who would rather pay the license fee even though they may not actually be using any of the technology held by the aggregator's valid patents.

Given this likelihood a remedy proposed by Areeda and Turner more than thirty years ago is worth considering. ${ }^{61} \mathrm{~A}$ firm that is in a position to earn supracompetitive returns from a patent should be relegated to a nonexclusive license for all patents obtained from outsiders. That is to say, the firm engaged in internal patenting, a presumptively innovative act, is in a much stronger position than the firm that acquires its patents from another. To be sure, a producing dominant firm needs someone else's patent in order to keep its own technology up do date. It has a legitimate interest in acquiring patents to the extent it intends to practice them. But a nonexclusive license will serve that purpose just as well as an exclusive license or assignment.

Why does a patent become more valuable in the hands of an acquirer of its former owner? One possibility is that a monopoly producer will earn more from it than a competitive producer could, but that rationale applies only to the firm that actually practices the patent. Another possibility is that uniting ownership of complementary patents may reduce double marginalization problems. Generally, when two or more firms with market power each licenses its own technology separately the sum of their individual prices will be higher than if one firm owned everyone's technology and licensed it together. This union benefits both licensors and licensees and thus might explain some instances of aggregation by non-practicing entities, although I am unaware of a specific example. ${ }^{62}$ But even here the aggregator needs only a nonexclusive license plus the right to sublicense. That is, by uniting two complementary patents into a common licensing agency and permitting them to sublicnse the agency will be able to offer a lower price for the two together than others can offer for each patent separately.

In any event, the NPE who knew or reasonably should have known about a standard setting procedure and voluntarily declined to participate should be held to the

${ }^{61}$ See 3 Phillip E. AREeda \& Donald F. Turner, Antitrust LaW II705d (1978). For the somewhat expanded current version, see 3 PhILLIP E. AREEDA \& HerberT HovenKamp, ANTITRUST LAW II707b-g (3d ed. 2008); and BOHANNAN \& HovENKAMP, supra note 4 at 293295 . To the best of my knowledge the proposal has not been adopted by any court.

${ }^{62}$ On double marginalization, see ERIK HovenKAMP \& HERBERT HovenKAMP, Tying Arrangements, in OXFORD HANDBOOK OF INTERNATIONAL COMPETITION LAW (2012), currently available at http://papers.ssrn.com/sol3/cf_dev/AbsByAuth.cfm?per_id=23858. On the problem with patents, see Mark A. Lemley \& Carl Shapiro, Patent Holdup and Royalty Stacking, 85 Tex. L. Rev. 2163 (2007). 
same remedy as actual participants - namely, FRAND damages. The Patent Act's standard for damages in this context is a "reasonable" royalty, and here the policy preference should be strong for competitively determined royalty rates rather than those based on ex post possibilities for holdup.

\section{Conclusion}

Solving problems of patent competition often requires a combination of antitrust and nonantitrust solutions. For example, eBay is not an antitrust case at all, but an equity decision concerned with private remedies generally. The Ninth Circuit's decision denying an injunction on FRAND-encumbered patents is similar. ${ }^{63}$ If the FRAND commitment exists at all, it is typically enforced under principles of contract law, or in some cases equitable estoppel, another equity doctrine that requires firms to make good on promises once others have acted in reliance. ${ }^{64}$ By contrast, anticompetitive patent transfers clearly fall within the heart of traditional antitrust concerns.

${ }^{63}$ Microsoft Corp. v. Motorola, Inc., __ F.3d _ , 2012 WL 4477215 (9 $9^{\text {th }}$ Cir. Sep. 28, 2012).

${ }^{64}$ E.g., Broadcom Corp. v. Qualcomm, Inc., 501 F.3d 297, 314 (3d Cir. 2007). 